\title{
Short Report: A déjeté Levallois tool from Khyber Pakhtunkhwa (Pakistan) and the role it plays in the chronology of the Pleistocene terraces of the Bannu Basin
}

\author{
Paolo Biagi ${ }^{1}$, Renato Nisbet ${ }^{1}$, Romana Haider ${ }^{2}$ \\ 1. Department of Asian and North African Studies (DSAAM), Ca’ Foscari University of Venice, Ca’ Cappello, \\ San Polo 2035, Venice I-30125, Italy. Email: Biagi: pavelius@unive.it; Nisbet: renato.nisbet@unive.it \\ 2. Taxila Institute of Asian Civilizations (TIAC), Quaid-i-Azam University, University Road, Islamabad 45320, \\ Pakistan. Email: romanahaidershah@gmail.com
}

\begin{abstract}
:
This paper discusses the importance of the discovery of one déjeté Levallois tool from the surface of a dark grey and black patinated gravel terrace located $c a .500 \mathrm{~m}$ south-west of the Neolithic site of Sheri Khan Tarakai in the Bannu Basin (Khyber Pakhtunkhwa, Pakistan), and provides a detailed geomorphological description of the area where it was found. The Neolithic site rests on a large gravelly fan, at present terraced and dismembered by small seasonal streams. Scatters of black varnished pebbles, at the top of a thick ochre silt of possible alluvial origin, cover its surface. Amongst the numerous siliceous gravels forming the deposit, some are of a good quality chert, whose source can be found in the Tertiary Sulaiman Formation. The typological characteristics of the tool, the chert employed for its manufacture, its location and the presence of black patina on its cortex are all important elements that contribute to the definition of the Pleistocene period during which pebble terraces formed. The tool comes from a region where Middle Palaeolithic artefacts had never been found before, though the reanalysis of old collections would suggest their presence as far as the course of the Indus in Lower Sindh. Moreover, its discovery contributes to the study of the south-eastern spread of the Middle Palaeolithic Levallois technique, an important topic that still needs to be fully understood.
\end{abstract}

Keywords: Pakistan; Bannu Basin; Pleistocene terraces; Geomorphology; Middle Palaeolithic; Levallois technique

\section{Introduction}

The scope of this paper is to discuss the chronology of the Pleistocene terraces on which the Neolithic settlement of Sheri Khan Tarakai is located. It is well known that old Quaternary terraces are very difficult to date without the help of chronologically reliable palaeontological or archaeological evidence. In this respect, the discovery of one Middle Palaeolithic Levallois tool on the surface of one of the terraces located $c a .500 \mathrm{~m}$ south-west of the site, provides new elements for the interpretation of the geomorphology and chronology of these features. The Neolithic village of Sheri Khan Tarakai is located in the western part of the Bannu Basin ISSN: 2055-0472. URL: http://journals.ed.ac.uk/lithicstudies/ 
(Khyber Pakhtunkhwa, Pakistan), ca. $30 \mathrm{~km}$ from the mountains of Waziristan. More precisely, the site rests at the top of a wide low alluvial terraced fan covered with black patinated pebbles and cobbles (Khan et al. 1988) (Figure 1).

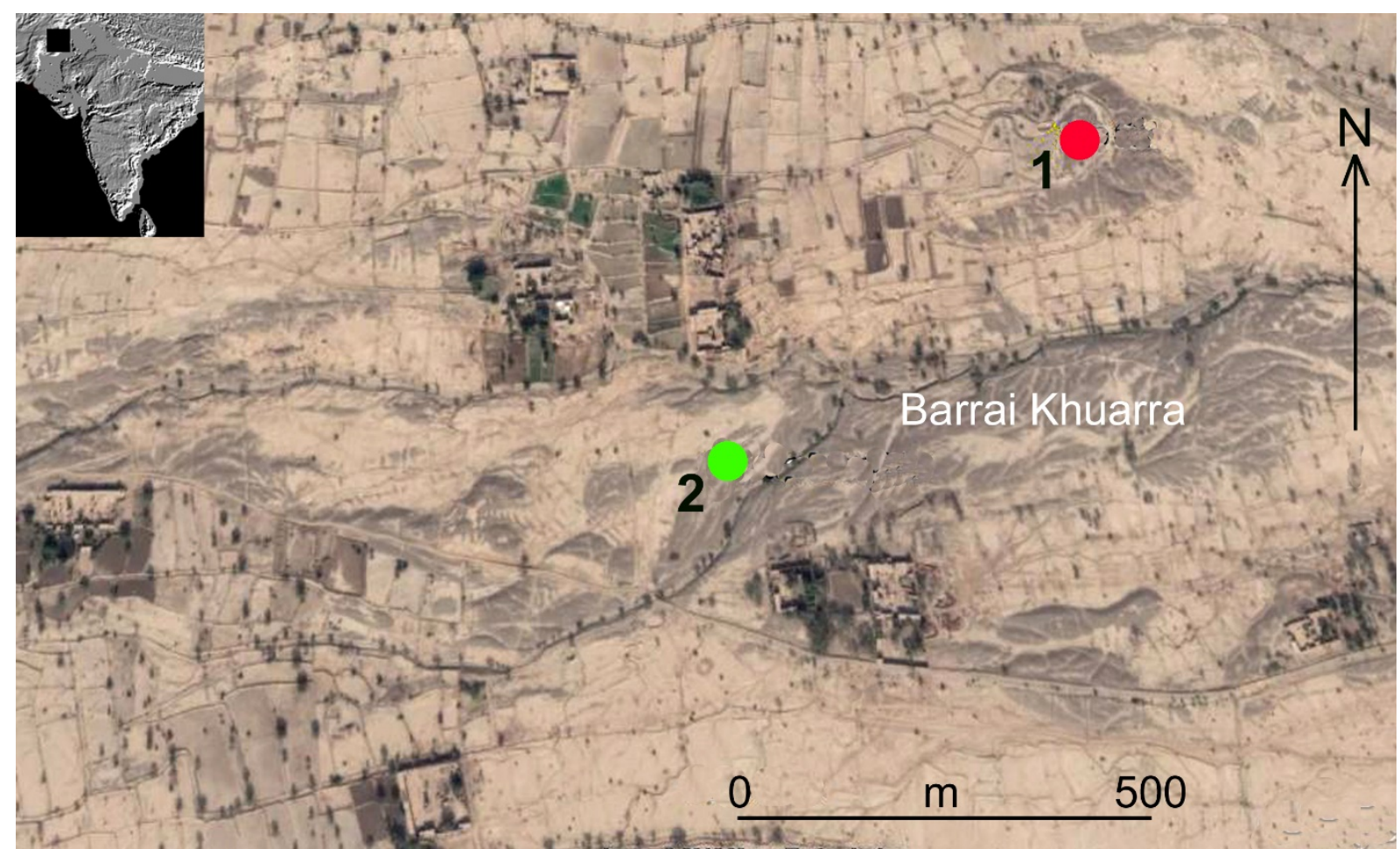

Figure 1. Locations of the Levallois tool on the gravel terraces of Barrai Khuarra (n. 2) and the Neolithic site of Sheri Khan Tarakai (n. 1) (drawing by P. Biagi, 2019).

Archaeological research in Bannu began in 1985 under the auspices of the Bannu Archaeological Project (henceforth BAP), while the excavation of the Neolithic site of Sheri Khan Tarakai were carried out between 1986 and 1990. The site yielded many archaeological features, among which are stone foundations and walls, floors, pits, mud-bricks, and other structures. The associated cultural remains are considered characteristic of a local aspect of the Late Neolithic, called Sheri Khan Tarakai phase. Its chronology is suggested to fall between $c a$. 3800 and 2900 cal BCE (Khan et al. 2010: 352).

During the years that followed the beginning of the research in the region, several papers and books were published regarding the archaeology of this remote territory of which almost nothing was known until the second half of the 1980s. Among the many results achieved by the BAP are the definition of the archaeological cultures that characterised the area between the Neolithic and the Historic period, and the absolute chronology of all the excavated sites. Moreover, a few knapped stone artefacts attributable to earlier Holocene and Pleistocene periods were also discovered in the area (Allchin et al. 1986: 65; Ambers \& Bowman 2003; Khan et al. 1986; 1987; 1988; 1989; 1991: 5-7, 151; 2001; 2010: 196, 464; Thomas 1986; 2002; 2003; Thomas \& Knox 1994).

\section{Geomorphologic setting}

The Bannu Basin is part of the thrust belt of northern Pakistan. It is delimited by the Kohat Plateau in the north, the Surghar Range in the east, the Marwat and Khisor Ranges in the south, the Pezu-Bhittani Range in the south-west, and the Waziristan-Sulaiman Range in the west. During the Quaternary, different depositional events led to the silting of large areas of the basin, with sands and silts of probable lacustrine origin accumulated in its central- eastern parts (Abir 
et al. 2017). This fact was in some ways envisaged already by the geomorphologic observations made during the second half of the $19^{\text {th }}$ century (Raverty 1888: 424-426; Thorburn 1876: 1-11) and in the first half of the $20^{\text {th }}$, within the discussion of the much-debated origin of the so-called Bain Boulder-beds in the south of the Bannu Basin (Morris 1938). Recent resistivity data (Farid et al. 2014) seem to confirm the existence of shallow Pleistocene lakes in the southern part of the basin as previously suggested by H. Rendell (Rendell 1981). Moreover, laminated lacustrine sediments are known from a quarry located near Lakki Marwat (personal communications with $\mathrm{K}$. Thomas in 2019). In particular, faulting and uplifting consequent to the Himalayan orogenic stress have interested the whole southern sector. They caused the uplift of the Bhittani and Marwat Ranges and the consequent formation of a large subsided depression that was later filled with lacustrine, fine alluvial sediments which form a large part of the Bannu Basin. PreHolocene erosional and depositional cycles exerted by the Kurram, Tochi and Gambila Rivers (the last is the name of the lower course of the Tochi) and their many tributaries that flow from the neighbouring ranges, led to the formation of large fans, terracing and coarse sediments deposition with gravel, pebbles and sand interstratified with clay beds (Farid et al. 2014).

During a short trip to Bannu made in July 2019, we visited some of the most important archaeological sites excavated by the BAP. A morphological aspect that characterizes many Neolithic and Bronze age sites consists in the recurrent presence of dark grey or black varnished pebbles covering part of the surface of the terraces on which the sites are located, as was already reported in detail by previous researchers. Such elements were observed at many archaeological settlements, among which are Tarakai Qila, on the right terrace of Tochi River (Ambers \& Bowman 2003: 537), Lewan (Allchin et al. 1986: 89-102), and Sheri Khan Tarakai (Khan et al. 2010: 30). As early as 1876, S. S. Thorburn described in a picturesque though realistic way, the same aspect that he observed in the Marwat: "a vast treeless plain of undulating sandy downs, merging to the west into a fringe of soft loamy clay, furrowed, as with some giant's plough, with numerous deep narrow water-courses, which converge almost at the same point, in the Gambila, or lose themselves before reaching it in the sand. Immediately under the hills to the west this loamy soil is overlaid by a layer of gravel, and smooth rounded stones, called by the people 'dózakhi kánri' or 'hell stones', owing to the black scorched appearance, which have been washed down from the hills during the long ages that had elapsed since God said: 'Let the dry land appear" (Thorburn 1876: 7).

More recently, the impression that the dark grey or black pebbles surfaces should be considered much older than the Late Holocene archaeological materials lying just above and among them was taken into consideration. Khan et al. (1991: 4, 151), who undoubtedly recognised the nature of the problem, discussed the presence of alleged Palaeolithic artefacts from seven sites discovered in the southern and western parts of the Bannu Basin. In particular, they described the terrace remnants at Dre Ghundheri Pickets amongst which several 'old' age artefacts were collected, whose surface is "covered in extensive spreads of pebbles and cobbles, most of which were heavily coated with desert varnish" (Khan et al. 1991: 4). The technotypological analysis of the knapped stone artefacts did not allow the authors to define their precise chrono-cultural attribution, though they expressed the opinion that their antiquity was granted by the heavy dark patina covering most of the tools, for which "dates possibly in excess of 30,000 BP may be suggested" (Khan et al. 1991: 5).

The site of Sheri Khan Tarakai (central point: N3250'32.0” - E70²8'25.9”, $408 \mathrm{~m}$ asl: Figure 1, n. 1) rests on a wide fan, dissected into several large terraces by the Barrai Khuarra seasonal stream that flows just south of the archaeological area that during some earlier Holocene periods was undoubtedly more important and active than it is nowadays (Khan et al. 2010: 41). Dark varnished pebbles cover an area of ca 30 ha uphill (0.3 square km) (Figure 2). They form the present top of the terraced coalescent fans that overlie a thick deposit of silt of alluvial origin (Figure 3). Chert sources are found mostly in the Tertiary rocks of the Sulaiman 
foothills, though they are known also in the upper part of the Habib Rahi Limestone and in the Chaudhwan Formation conglomerates ca. $120 \mathrm{~km}$ to the south (Hemphill \& Kidwai 1973: 543; Thomas et al. 2010). Their outcrops would have provided a variety of lithologies of excellent quality for the production of prehistoric knapped stone artefacts (Figure 4). According to Inizan et al. (1994: 247), the knappable material from Sheri Khan Tarakai consists of "fine grained homogeneous flint" that is perfectly consistent with our July 2019 observations. This opinion contrasts with that of J. C. Morris et al. (2001: 137). These authors described the presence of microcrystalline to cryptocrystalline quartz, more simply chert, from both the Tochi River bed and the Sheri Khan Tarakai terraces. According to them the material is of a "poor quality, probably as a result of the sequence of erosion, weathering, and deposition" (Morris \& Khan 2010: 196), though we noticed a great difference in both structure, quality and colour between the knappable raw materials sampled from the two areas. Isolated outcrops of the Habib Rahi Limestone Member are known also along the western part of the Tochi River Valley, much closer to Sheri Khan Tarakai.

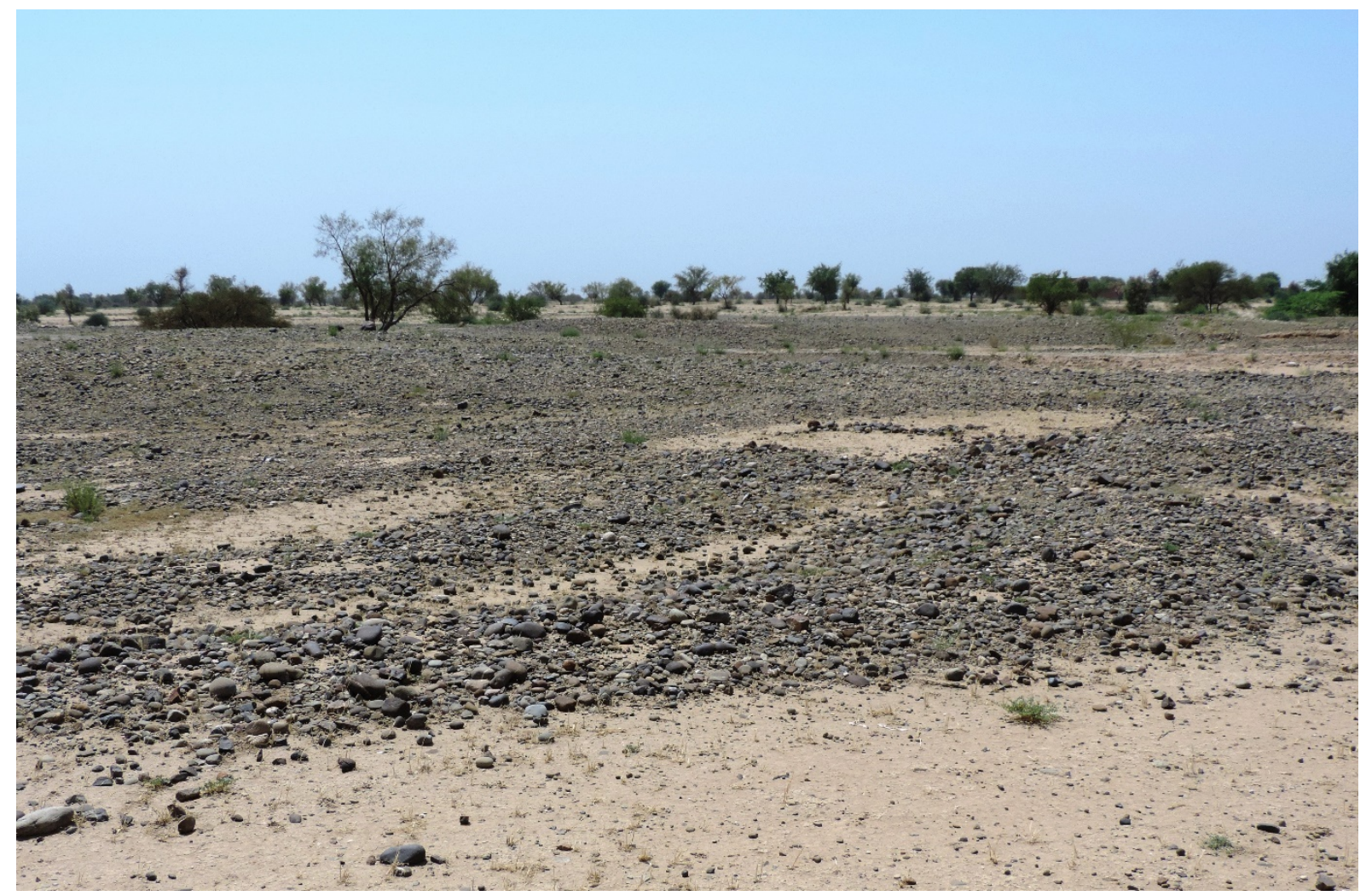

Figure 2. Dark grey and black varnished gravel terraces south of the course of Barrai Khuarra (photograph by R. Nisbet, 2019). 


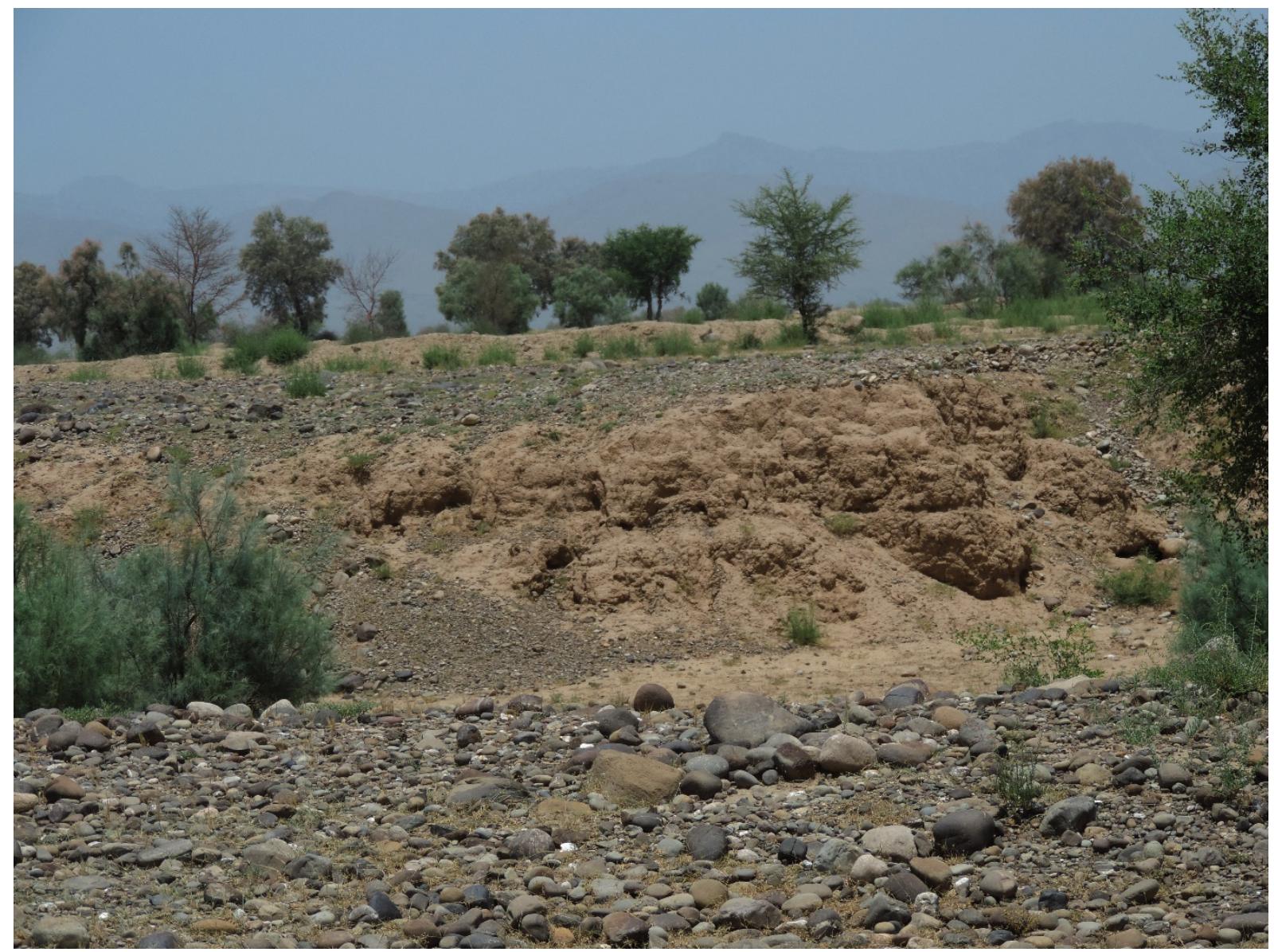

Figure 3 A thick deposit of silt of alluvial origin covered with a layer of dark grey and black varnished gravels south of the course of Barrai Khuarra (photograph by R. Nisbet, 2019).

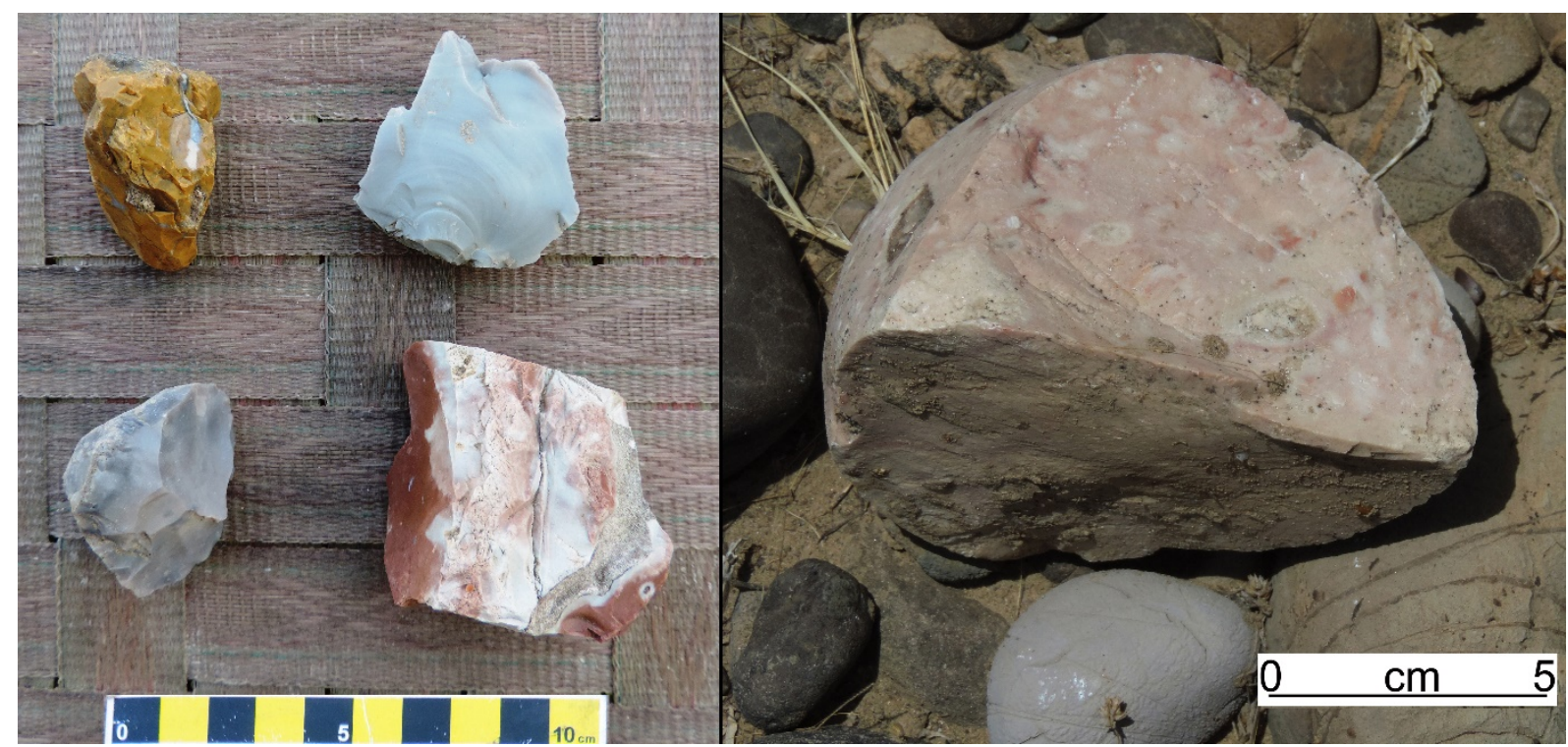

Figure 4. Natural chert pieces (left) and nodule (right) from the gravel terraces of Barrai Khuarra (photographs by R. Nisbet, 2019). 


\section{The Levallois tool}

The knapped stone implement discussed in this paper was incidentally discovered by one of the writers (RN) on the surface of a dark varnished pebble terrace at point N32 50 '18.7'E70²8'10.3” (409 m asl), ca. $500 \mathrm{~m}$ south-west of the Neolithic site of Sheri Khan Tarakai (Figure 1, n. 2). The tool was found reversed, in a horizontal position with its ventral face exposed. From a typological point of view the tool is a déjeté Levallois convergent tool with a dihedral, partly facetted, "chapeau de gendarme" platform. It was obtained from a ca. $5 \mathrm{~cm}$ wide, and at least $7.5 \mathrm{~cm}$ long, oval pebble of good-quality white chert (2.5Y8/1). Its width is deduced from the presence of small traces of the original dark grey colour (7.5YR4/1) varnished cortex along both sides (Figure 5; Figure 6, nn. 1 and 4). The maximum measures of the point, taken from the platform's axis, are $6.1 \times 5.6 \times 1.2 \mathrm{~cm}$ (Length, Width and Thickness). A few, very small notches are visible on both sides, most probably caused by trampling (Figure 6, nn. 2-4). The tool, weighing $32.70 \mathrm{~g}$, is covered with a thick, translucent, pale yellow patina due to exposure (2.5Y7/3) (Munsell Soil Color Charts 2000). It does not show other damages or rounded surfaces caused by rolling or (water) transport suggesting that it has been found in its primary position. The maximum thickness of the point was measured on the left side ridge, where a small portion of the original cortex is preserved, partly removed by a direct, scalar retouch. The cross-section is elongated, scalene, and triangular with slightly concave and convex surfaces.

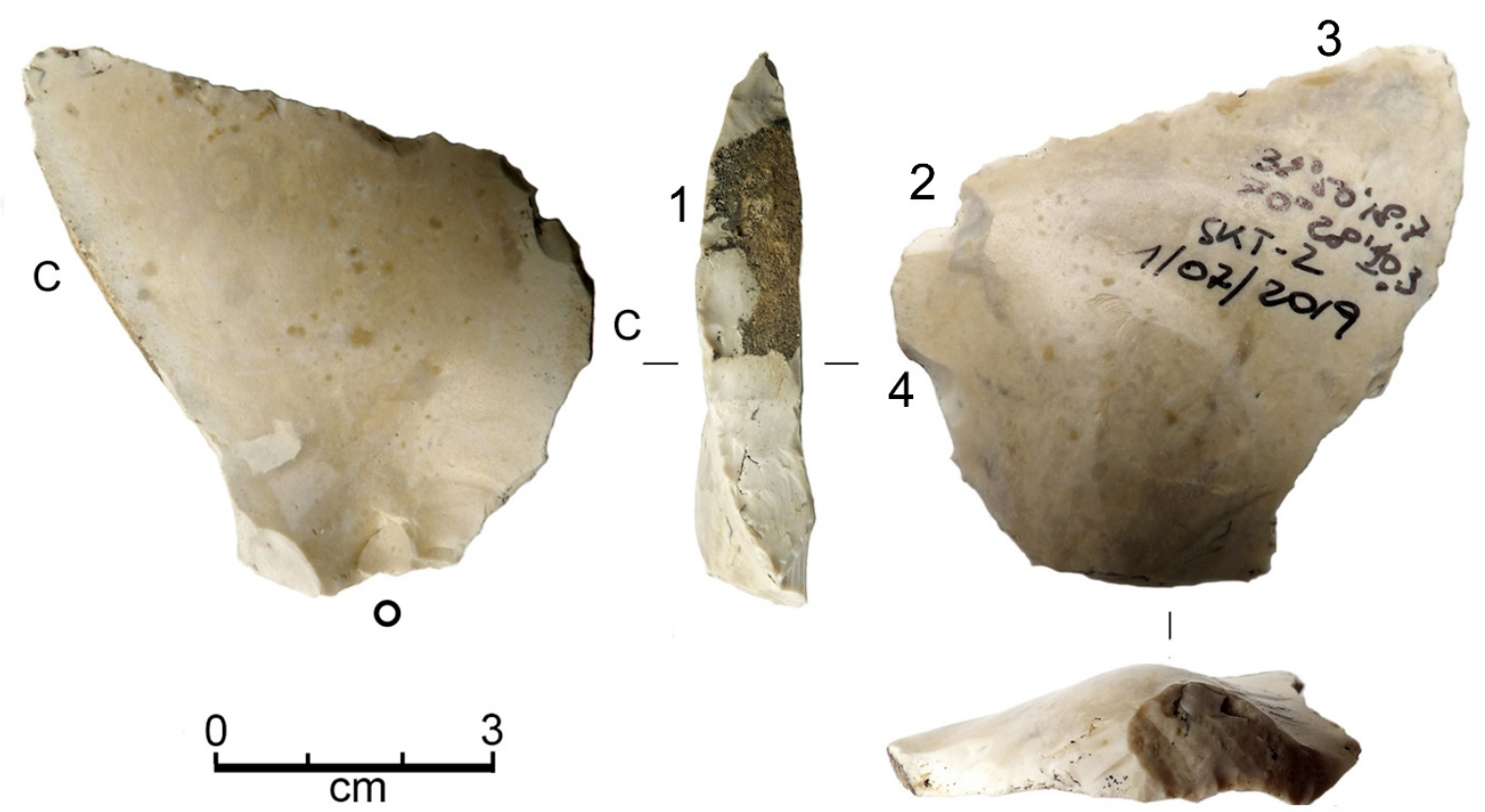

Figure 5. Déjeté Levallois tool recovered from the surface of a black varnished pebble terrace at point N32 ${ }^{\circ} 50^{\prime} 18.7^{\prime \prime}$ - E70²8'10.3”, ca. 500 m south-west of Sheri Khan Tarakai with the indication of the points where part of the original dark grey cortex covering the flint pebble is still preserved $(C)$, the points where the microphotographs of Figure 6 were taken (nn. 1-4), and the location of the platform (small circle) (photographs by E. Starnini, 2019).

The BAP had already discovered techno-chronologically undiagnostic Palaeolithic artefacts on the surface of the low hills of Dre Ghundheri Pickets, $c a$. $8 \mathrm{~km}$ west of Bannu City. They were described and partly illustrated by Khan et al. (1991: 4-7, fig. 5). Although they cannot be attributed to any defined Palaeolithic period. In any case, Levallois artefacts are not reported from the hills of Dre Ghundheri Pickets by the above authors. Other probably earlier Palaeolithic artefacts were published by T. O. Morris (Morris 1938: 412, fig. 9), though they 
come from the southernmost part of the Bannu Basin (Pezu-Malagan area), and were recovered from very different geomorphologic locations.
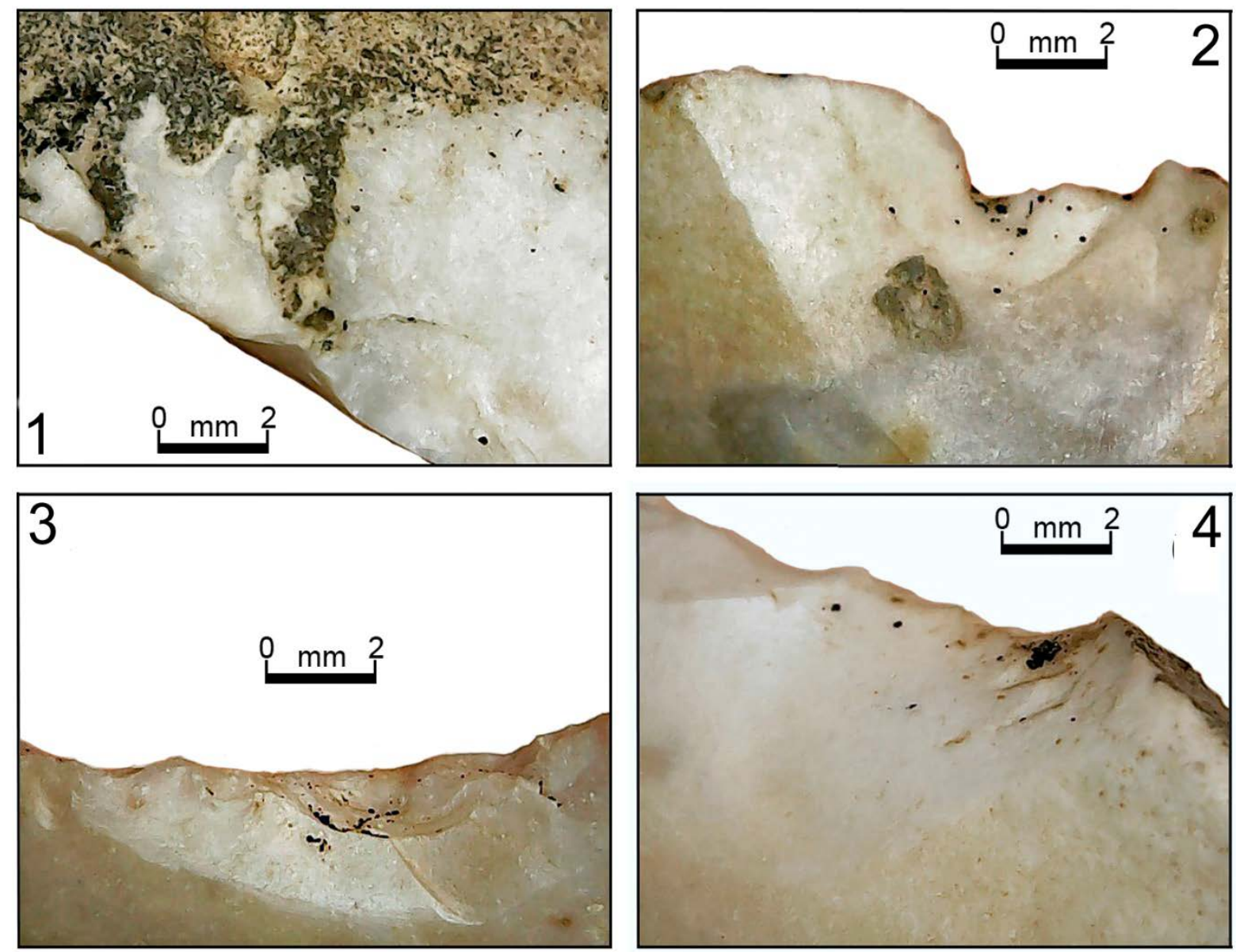

Figure 6. Microphotographs of four different points of the Levallois tool on which part of the original cortex is preserved (nn. 1 and 4) and small breakages are visible (nn. 2-4). Numbers indicate their positions in Figure 5 (photographs by E. Starnini, 2019).

\section{Discussion}

The discovery of a déjeté Levallois tool in the Bannu district of north-western Pakistan is important because it can help date the formation of the black varnished pebble terraces on the surface of which it was collected that according to our data are to be attributed to a Pleistocene period probably earlier than 50-40,000 BP. Moreover it contributes to the study of the distribution of Middle Palaeolithic Levallois technique in the Indian Subcontinent, a topic that is still badly known (Bar-Yosef 2013: fig. 2.1) and interpreted in different ways (Biagi \& Starnini 2014).

The discovery of the Levallois tool may suggest the impressions already put forward regarding the Pleistocene attribution of the terraces. Consequently, the presence of heavily patinated tools on the surface of some of these features seem to confirm that they formed most probably well before the tool was discarded (Khan et al. 1991: 5). The presence of this tool would therefore represent at least a possible terminus ante quem for the terrace formation.

Moreover, the re-analysis of old collections, and the discovery of new, characteristic knapped stone artefacts in Pakistan show that Middle Palaeolithic Levallois assemblages are attested at least as far as the course of the Indus River in Lower Sindh (Biagi \& Starnini 2018). At present, the evidence of Levallois assemblages is however very scarce in the north-western 
regions of the Subcontinent (Nishiaki \& Akazawa 2018: 5) most probably because of the absence of research in the region. They are known from the cave of Darra-i-Kur in north-eastern Afghanistan (Dupree \& Davis 1972), where they are still undated (see Douka et al. 2017), as well as in the easternmost part of South Khorasan (Iran) (Nasab 2011: fig. 1), not far from one of the suggested dispersal, migratory routes across the Iranian plateau towards Afghanistan (Nasab et al. 2013: fig. 10; see also Heydari-Guran et al. 2015).

\section{Acknowledgements}

This paper has been written thanks to the financial support of the Italian Ministry of Foreign Affairs (MAE). The authors are very grateful to Dr Ali Shah Haider for all his help and the organization of our trip to Bannu, as well as to Abdul Hussain, Chief of the Mian tribe, who provided hospitality, every sort of facility and security during our 2019 permanence in his Bannu City residence.

Special thanks are due to Professor K. Thomas (UCL, UK) for his comments, suggestions and for providing new information regarding the site of Sheri Khan Tarakai and its surrounding landscape, and to Professor A. Carton (Padua University, Italy) for providing old papers on the geology of Bannu Basin.

\section{References}

Abir, I.A., Khan, S.D., Aziz, G.M. \& Tariq, S. 2017, Bannu Basin, fold-and-thrust belt of northern Pakistan: Subsurface imaging and its implications for hydrocarbon exploration. Marine and Petroleum Geology, 85: 242-258. doi:10.1016/j.marpetgeo.2017.05.023

Allchin, F.R., Allchin, B., Durrani, F.A. \& Khan, F.M. (Eds.) 1986, Lewan and the Bannu Basin: Excavation and Survey of Sites and Environments in North West Pakistan. BAR International Series, Vol. 310. Archaeopress, Oxford, 283 p.

Ambers, J. \& Bowman, S. 2003, Radiocarbon Measurements from the British Museum: Datelist XXVI. Archaeometry, 45 (3): 531-540. doi:10.1111/1475-4754.00126

Bar-Yosef, O. 2013, Neanderthals and Modern Humans Across Eurasia. In: Dynamics of Learning in Neanderthals and Modern Humans Volume 1: Cultural Perspectives (Akazawa, T., Nishiaki, Y. \& Aoki, K., Eds.), Replacement of Neanderthals by Modern Humans Series. Springer, Tokyo: p. 7-20. doi:10.1007/978-4-431-54511-8_2

Biagi, P. \& Starnini, E. 2014, The Levallois Mousterian assemblages of Sindh (Pakistan) and their relations with the Middle Palaeolithic of the Indian Subcontinent. Archaeology, Ethnology and Anthropology of Eurasia, 42-(1): 18-32. doi:10.1016/j.aeae.2014.10.002

Biagi, P. \& Starnini, E. 2018, Neanderthals and Modern Humans in the Indus Valley? The Middle and Late (Upper) Palaeolithic settlement of Sindh, a forgotten region of the Indian Subcontinent. In: The Middle and Upper Paleolithic Archeology of the Levant and Beyond (Nishiaki, Y. \& Akazawa, T., Eds.), Replacement of Neanderthals by Modern Humans Series. Springer, Singapore: p. 175-197. doi:10.1007/978-981-106826-3_12

Douka, K., Slon, V., Stringer, C., Potts, R., Hübnerb, A., Meyerb, M., Spoore, F., Pääbo, S. \& Higham, T. 2017, Direct radiocarbon dating and DNA analysis of the Darra-i-Kur (Afghanistan) human temporal bone. Journal of Human Evolution, 107: 86-93. doi:10.1016/j.jhevol.2017.03.003 
Dupree, L. \& Davis, R.S. 1972, The lithic and bone specimens from Aq Kupruk and Darra-iKur. Prehistoric Research in Afghanistan (1959-1966). Transactions of the American Philosophical Society, 62(4): 14-32. doi:10.2307/1005969

Farid, A., Khalid, P., Jadoon, K.Z. \& Jouini, M.S. 2014, The depositional setting of the Late Quaternary sedimentary fill in southern Bannu basin, Northwest Himalayan fold and thrust belt, Pakistan. Environmental Monitoring and Assessment, 186-(8): 3-20. doi:10.1007/s10661-014-3876-5

Hemphill, W.R. \& Kidwai, A.H. 1973, Stratigraphy of the Bannu and Dera Ismail Khan Areas, Pakistan. Geological Investigations in Pakistan. Geological Survey Professional Paper 716-B. Pakistan Geological Survey, Quetta, 44 p. doi:10.3133/pp716B

Heydari-Guran, S., Ghasidian, E. \& Conard, N.J. 2015, Middle Paleolithic Settlement on the Iranian Central Plateau. In: Settlement Dynamics of the Middle Paleolithic and Middle Stone Age, Volume 4 (Conard, N.J. \& Delagnes, A., Eds.), Tübingen Publications in Prehistory, Kerns Verlag, Tübingen: p. 171-203.

Inizan, M.-L., Lechevallier, M. \& Pelegrin, J. 1994, The use of metal in the lithics of Sheri Khan Tarakai, Pakistan: evidence provided by the technological approach of pressure debitage. In: South Asian Archaeology 1993 (Parpola, A. \& Koskikallio, P., Eds), Annales Academiæ Scientiarum Finnicæ, Series B, number 271, Suomalainen Tiedeakatemia, Helsinki: p. 245-262.

Khan, F., Knox, J.R. \& Thomas, K.D. 1986, Sheri Khan Tarakai a new site in the North-West Frontier Province of Pakistan. Journal of Central Asia, 9: 13-34.

Khan, F., Knox, J.R. \& Thomas, K.D. 1987, The Bannu Archaeological Project a study of prehistoric settlement in Bannu District, Pakistan. South Asian Studies, 3: 83-90. doi:10.1080/02666030.1987.9628359

Khan, F., Knox, J.R. \& Thomas, K.D. 1988, Prehistoric and Protohistoric Settlements in Bannu District. Pakistan Archaeology, 23 (1987-1988): 99-148.

Khan, F., Knox, J.R. \& Thomas, K.D. 1989, New perspectives on early settlement in Bannu District, Pakistan. In: South Asian Archaeology 1985 (Frifelt, K. \& Sørensen, P., Eds). Curzon Press, London: p. 281-291.

Khan, F., Knox, J.R. \& Thomas, K.D. 1991, Explorations and Excavations in Bannu District. North-West Frontier Province. Pakistan. 1985-1988. British Museum Occasional Paper, Vol. 80. The British Museum Press, London, 151 p.

Khan, F., Knox, J.R. \& Thomas, K.D. 2001, Bannu: A melting pot for cultural change in the proto-historic periods. In: Indus Valley Civilization: Dialogue Among Civilizations (Halim, M.A. \& Ghafoor, A., Eds.), Ministry of Minorities, Culture, Sport, Tourism \& Youth Affairs Government of Pakistan, Islamabad: p. 71-96.

Khan, F., Knox, J.R., Thomas, K.D., Petrie, C.A. \& Morris, J.C. 2010, Sheri Khan Tarakai and early village life in the borderlands of north-west Pakistan. Oxbow Books, Oxford, $464 \mathrm{p}$.

Morris, J.C., Ashton, N. \& Hook, D. 2001, The Lithic Assemblage from the Neolithic Site of Sheri Khan Tarakai, NWFP, Pakistan: The Technological Interpretation and the Resultant Socio-Economic Implications. Paléorient, 27-(1): 127-139. URL: https://www.persee.fr/doc/paleo_0153-9345_2001_num_27_1_4724 
Morris, J.C. \& Khan, F. 2010, Struck lithics from Sheri Khan Tarakai. In: Sheri Khan Tarakai and early village life in the borderlands of north-west Pakistan (Khan, F., Knox, J.R., Thomas, K.D., Petrie, C.A. \& Morris, J.C., Eds.), Oxbow Books, Oxford: p. 195-210.

Morris, J.C. \& Thomas, K.D. 2002, Excavations at the Later Prehistoric Site of Lewan, NorthWest Frontier Province, Pakistan. Papers from the Institute of Archaeology, 13: 94-100. doi:10.5334/pia.178

Morris, T.O. 1938, The Bain Boulder Bed: a glacial episode in the Siwalik Series of the Marwat Kundi Range and Shekh Budin, North-West Frontier Province, India. Quarterly Journal of the Geological Society of London, 94: 385-421. doi:10.1144/GSL.JGS.1938.094.01-04.15

Munsell Soil Color Charts 2000. GretagMacbeth, New Windsor, NY, 10 p. 23 sheets.

Nasab, H.V. 2011, Paleolithic Archaeology in Iran. International Journal of Humanities, 18(2): 63-87. URL: http://eijh.modares.ac.ir/article-27-1985-en.html

Nasab, H.V., Clark, G.A. \& Torkamandi. S. 2013, Late Pleistocene dispersal corridors across the Iranian Plateau: A case study from Mirak, a Middle Paleolithic site on the northern edge of the Iranian Central desert (Dasht-e Kavir). Quaternary International, 300: 267281. doi:10.1016/j.quaint.2012.11.028

Nishiaki, Y. \& Akazawa, T. 2018, Archaeological Issues in the Middle and Upper Paleolithic of the Levant and its Neighboring Regions. In: The Middle and Upper Paleolithic Archeology of the Levant and Beyond (Nishiaki, Y. \& Akazawa, T., Eds.), Replacement of Neanderthals by Modern Humans Series. Springer, Singapore: p. 1-7. doi:10.1007/978-981-10-6826-3_1

Raverty, H.G. 1888, Notes on Afghanistan and Part of Baluchistan, Geographical, Ethnographical, and Historical. Eyre and Spottiswoode, London, 746 p.

Rendell, H. 1981, A Preliminary Investigation of the Sedimentary History of the Bannu Basin in the Late Holocene. In: South Asian Archaeology 1979 (Härtel, H., Ed.), Dietrich Reimer Verlag, Berlin: p. 219-225.

Thomas, K.D. 2003, Minimazing Risk? Approaches to Pre-Harappan Human Ecology of the North-West Margin of the Greater Indus System. In: Indus Ethnobiology. New Perspectives from the field (Weber, S.A. \& Bercher, W.R., Eds.), Lexington Books, Oxford: p. 397-342.

Thomas, K.D. 1986, Environment and Subsistence in the Bannu Basin. In: Lewan and the Bannu Basin: Excavation and Survey of Sites and Environments in North West Pakistan (Allchin, F.R., Allchin, B., Durrani, F.A. \& Khan, F.M., Eds.), BAR International Series, 310. Archaeopress, Oxford: p. 13-33.

Thomas, K.D., Khan, F. \& Petrie, C. 2010, The physical and human geography of the Bannu Basin. In: Sheri Khan Tarakai and early village life in the borderlands of north-west Pakistan (Khan, F., Knox, J.R., Thomas, K.D., Petrie, C.A. \& Morris, J.C., Eds.), Oxbow Books, Oxford: p. 29-40.

Thomas, K.D. \& Knox, J.R. 1994, Routes to passage: Later prehistoric settlement and exploration of a frontier region in northwestern Pakistan. Bulletin of the Institute of Archaeology, London, 31: 89-104.

Thorburn, S.S. 1876, Bannu; or our Afghan frontier. Trübner \& Co., London, 504 p. 